\title{
Corporate Governance, Family Ownership and Firm Value: Indonesia Evidence
}

\author{
Mariana Ing Malelak ${ }^{1 *}$, Christina Soehono ${ }^{1}$, and Christine Eunike ${ }^{2}$ \\ ${ }^{1}$ Finance Program, Faculty of Business and Economics, Petra Christian University, \\ Jl. Siwalankerto No.121-131, Siwalankerto, Surabaya 60236 Indonesia \\ ${ }^{2}$ International Finance, Shanghai University of Finance and Economics, 318 Wuchuan Rd, \\ Shanghai, 200083, China
}

\begin{abstract}
The research objective to assess the influence of corporate governance and family ownership on firm value non-financial firms listed in Indonesia. The board and ownership structure were representing corporate governance characteristics. The board structure consists of commissioners, directors and independent commissioners, while the structure of ownership consists of institutional, public and managerial ownership. This research used data non-financial firms listed in Indonesia Stock Exchange period 2008 to 2018. Using purposive sampling as technique's to filter the samples and panel data analysis method. The results of research state that corporate governance (board and ownership structure) and family ownership simultaneously have a significant influence on firm value. Partially, independent commissioners, board of directors, public and institutional ownership have a significant influence on firm value. Meanwhile the board of commissioners, managerial and family ownership have no significant influence on firm value.
\end{abstract}

Keywords: Board structure, independent commissioners, institutional ownership, managerial ownership, public ownership, structure of ownership.

\section{Introduction}

A company is founded to achieve long-term goals, to maximize the wealth of shareholders. In the process of maximizing shareholder wealth, problems often arise called agency problems, which are problems that occur because of different interests between owners and managers. One of the methods used to minimize agency problems is implementing good corporate governance. Corporate governance is a system used by the board to direct, control and supervise the management of organizational resources effectively, efficiently, economically, and productively in order to achieve organizational goals [1].

In this study the variables used to assess corporate governance are board structure and ownership structures. Study on corporate governance [2], stated that size of the board, leverage and revenue have a significant effect on firm value while insider ownership have no significant effect on firm value. Heenetigala and Armstrong [3], found a positive influence on the implementation of corporate governance practices such as separate

* Corresponding author: mariana.ing@ @eter.petra.ac.id 
leadership, board committee and board composition with company performance (as measured by return on equity, return on assets and Tobin's Q). Thus, concluded that companies that implement a strategy of good corporate governance, tend to have the ability to produce higher financial performance and have higher firm value, which can be seen through an increase in the company's stock price in the long-term.

Besides corporate governance, ownership structure is one mechanism that can influence agency problems. Firms with lower concentrations of family ownership tend to have less conflict between agents and principals. The concentrated ownership structure will increase the management supervision therefore agency problems can be more resolved or minimize agency problem [4]. In addition, Barontini and Caprio [5] stated that family control has a positive influence on firm's values. Price water house Coopers (PwC) Indonesia [6], stated that a firm is referred to as a family firm if the founder who acquires the firm (or his family) has $25 \%$ rights to the company through investment and there is at least 1 member of family in board (management). Andres [7] classifies family firms as firms with at least $25 \%$ shares owned by a particular family or if less than $25 \%$ of family members hold positions on the company's board of directors or board of commissioners. The prior research, supported by the results of a survey conducted by PwC in November 2014, found that more than $95 \%$ of businesses in Indonesia are owned by families. $100 \%$ have family members with senior executive positions in the company, $53 \%$ have family members working in the company but not as senior executives, $53 \%$ have family members who do not work in the company but have company shares and $17 \%$ have family members who do not work in company or own company shares, but involved in other ways. Thus, mean that the involvement of family members has an important role in the family business.

Family ownership in Indonesia is generally a family business enterprise (FBE), a firm that is owned and managed by family members of the company's founders, both ownership and management are held by the family. Family firms eventually can be morph from family business enterprise (FBE) to family owned enterprise (FOE), which is a family-owned company but managed by professional executives from outside the family (managed by non-family member. The better management of a family firms, whether carried out by family members themselves or professional executives who are not family members, has the same goal of increasing the value of the firm, the higher firm value is expected to increase the wealth of shareholders. Tobin's Q will use to measure the firm value [8].

The research results of this study can present the evidence of the influence of corporate governance and family ownership on the firm's value of non-financial firms listed on the Indonesia Stock Exchange in the period 2008 to 2018. Second, the results of the study can be used to implement better corporate governance for non-financial firms that have family ownership in the firm. Besides, investors can used the information to take better investment decision and will open new horizons in research for researcher, especially the issues about corporate governance, family ownership and firm value.

\section{Literature review}

Agency theory discusses the relationship between shareholders as principals, managers and bondholders [9]. The principal (shareholders) entrusts the management to the managers, to fulfill the shareholders interest. Therefore, managers are responsible and must report their activities to shareholders. Managers and shareholders are often in conflict, managers are more likely to prioritize their personal interests rather than the interests of shareholders [10]. Pujiastuti [9] stated that agency conflicts can occur between (i) owners (shareholders) and managers, where managers tend to improve their own wealth. This is contrary to shareholders, where shareholders tend to want to increase profits through dividends and increase the company's stock price. (ii) Managers with debtholders, where managers prefer 
retained dividends to be used as capital for company expansion, whereas debtholders prefer that retained dividends are used as funds to pay company debts. Debtholders worry if the profits used for company expansion do not match what is expected thus company debt cannot be paid. Agency conflicts can be reduced by controlling the behavior of managers. Controlling agency conflicts requires agency costs which can be expenses to monitor the managers, opportunity costs to earn profits due to limited authority or differences in decisions between the principal and agents or managers [11]. Agency costs are costs borne by shareholders to prevent or minimize agency problems, if the agency problem decreases, the firm is expected to be able to focus on increasing the firm's value (or maximizing shareholder wealth).

\subsection{Corporate governance}

Corporate governance is a system where the firms is directed and controlled. Corporate governance is rules governing relation between all parties in the firms, such as stakeholders, management, employees, creditor, the government, and external stakeholders of the firms relating to their rights and obligations [12]. The important to implement corporate governance in the firms, because it is a system that regulates and controls the firm, thus enable firms to create value-added for all stakeholders [13]. There are two important things in this concept: i) the importance of shareholder right to obtain the correct information and in time, ii) mandatory for the firms to make disclosure to be accurate, timely, transparency for all information about firm performance, ownership and stakeholders. Firms need to pay attention to five principles of corporate governance: transparency, accountability, responsibility, independency, and fairness.

\subsection{Family ownership}

Research conducted by Andres [7] classified a family firm as a firm whose shares are at least $25 \%$ owned by a certain family or if less than $25 \%$ have family members who have positions on the board of directors or the board of commissioners of the firm. Some other studies use a percentage of $5 \%$ as the number of shares that must be owned by the family [14]. While other research conducted by [15] classified a family firm if a family has a minimum of $33 \%$ of the company's total shares. The majority family firms listed on Indonesian Stock Exchanges has the closely held ownership, therefore there are two groups of shareholders, controlling and minority shareholders, and sometimes the family firms listed on stock exchange, is one of the unit of a particular business group, which often occurs self-dealing problems are detrimental to minority shareholders. The agency problems also occur in companies belonging to state-owned enterprises, lack of transparency and good control systems (including enforcement) raises the opportunity for the agent (the official representing of the owner or management) to take decisions which tend to favor themselves.

The variables of corporate governance found in several variables are board of director, commissioner, and independent commissioner, also in public, managerial and institutional ownership. This research used family ownership as second independent variable separately from ownership structure to assess whether the presence of family members in the firm will affect the firm value. Therefore, we assumed that board and ownership structure included family ownership has a significant influence on firm value. 


\section{Data and methodology}

\subsection{Data}

The data is collected by report from audited financial report of non-financial firms listed on the Indonesian Stock Exchange start from 2008 to 2018. Also, it is used non-financial firms, due to the different implication of the regulation between financial and nonfinancial firms. The purposive sampling filter the samples, based on criteria:

(i). Registered as a public firms on Indonesian Stock Exchange since 2008 to 2018 (never had a delisting)

(ii). Publish an audited annual report regularly

(iii). Presents the information about board and ownership structure

(iv). Firm should has directors or affiliated commissioners

\subsection{Research model}

Research model used a panel data analysis, because it used the $11 \mathrm{yr}$ as data period and 30 firms as samples, this method used to assess the influence of corporate governance (board and ownership structure) and family ownership on firm value, with the model:

$$
\begin{aligned}
& F V_{\mathrm{i}, \mathrm{t}}=\alpha+\beta 1 \text { BComi }_{\mathrm{i}, \mathrm{t}}+\beta_{2} \text { BDiri, }_{\mathrm{t}}+\beta_{3} \text { IComi }_{\mathrm{t}}+\beta_{4} \text { IOwni, }_{\mathrm{t}}+\beta 5 \text { MOwni, }+\beta 6 \\
& P O w n \mathrm{i}, \mathrm{t}+\beta 7 \text { FOwni,t } \varepsilon \mathrm{i}, \mathrm{t} \text {. }
\end{aligned}
$$

Where:

$B C o m=$ the number of the commissioner

$B D i r=$ the number of the director

ICom $=$ the number of the independent commissioner

IOwn $=\%$ shares owned by institutions

$M O w n=\%$ shares owned by the director

$P O w n=\%$ shares owned by public

$F O w n=\%$ shares owned by family member

$F V_{\mathrm{i}, \mathrm{t}}=$ firm value $i$ at time $t$

$\beta 1, \beta 2, \beta 3, \beta 4, \beta 5, \beta 6, \beta 7$ = coefficient regression of each firm.

$\varepsilon \mathrm{i}, \mathrm{t}=$ error term of firm $i$ at time $t$

Firm Value (FV) which is measured by market capitalization, with formula:

$\mathrm{Q}=(\mathrm{EMV}+\mathrm{D}) /(\mathrm{EBV}+\mathrm{D})$

$\mathrm{Q} \quad=$ firm value

EMV = equity market value $=$ closing price $\mathrm{x}$ number of shares outstanding

$\mathrm{EBV}=$ equity book value

$\mathrm{D}=$ book value of debt

BCom $=$ the sum of the members of the board of commissioners

BDir $=$ the sum of the board directors

ICom $=$ the sum of the independent commissioners involved in firm

IOwn $=\%$ shares owned by institutions, both government and private institution

MOwn $=\%$ shares owned by the firm's management

POwn $=\%$ shares owned by the public

Corporate governance was represented by the board and ownership structure, measured by: family members who have positions on the board of directors or the board of 
commissioners in the firms (which is measured by: Number of directors or affiliated commissioners / total commissioners and directors).

\section{Results}

Table 1. Descriptive statistics

\begin{tabular}{lrrrrrrrr}
\hline & FV & BCom & \multicolumn{1}{c}{ BDir } & ICom & \multicolumn{1}{c}{ IOwn } & MOwn POwnnn & FO \\
\hline Mean & 0.9686 & 4.7620 & 4.8733 & 2.7613 & 0.7877 & 0.0412 & 0.2684 & 0.2940 \\
Maximum & 3.8200 & 15.000 & 13.000 & 6.0000 & 0.9860 & 0.6720 & 0.9847 & 0.5712 \\
Minimum & 0.0720 & 0.0000 & 3.0000 & 0.0000 & 0.0000 & 0.0000 & 0.0760 & 0.0812 \\
Std. Dev. & 0.7033 & 3.1254 & 1.7103 & 1.1045 & 0.1106 & 0.0436 & 0.0859 & 0.7571 \\
Observations & 330 & 330 & 330 & 330 & 330 & 330 & 330 & 330 \\
\hline
\end{tabular}

Table 1. Showed, from 330 observations, the authors get the average firm value 96.86 $\%$, indicates that the book value of the firm's assets is almost the same as the firm's market value. In 2008 to 2018, the average number of directors and commissioner are around four to five persons, and the average number of independent commissioner is around two to three persons. The largest average value of ownership structure is in institutional ownership $78.77 \%$, then family ownership $29.40 \%$, followed by public ownership $26.84 \%$ and managerial ownership $4.12 \%$.

\subsection{Regression results}

This results of balance panel data regression with 330 observations.

Table 2. Balance Panel Data Regression Results

\begin{tabular}{lcccc}
\hline \multicolumn{1}{c}{ Variables } & Coefficient & Std. Error & Prob. & $\mathbf{R}^{2}$ \\
\hline C & 0.2019 & 0.1295 & 0.0083 & 0.7982 \\
BC BD IC IO MO & 0.0025 & 0.0074 & 0.8287 & \\
$\quad$ PO & -0.0315 & 0.0055 & $0.0366^{*}$ & Adjust R2 \\
& 0.0690 & 0.0125 & $0.0000^{*}$ & 0.7218 \\
& 0.2138 & 0.1270 & $0.0355^{*}$ & \\
FO & -0.4716 & 0.3445 & 0.0569 & \\
F Statistics & 0.5291 & 0.1385 & $0.0008^{*}$ & \\
Prob (F-Stat) & 0.8121 & 0.1457 & 0.3520 & \\
\hline
\end{tabular}

Table 2. Showed, from results, partially, only four variables from board and ownership structure, such as independent commissioner, number of director, public and institutional ownership have a significant influence on firm value, overall corporate governance and family ownership have a significant effect on firm value. Have Adj-R2 $72.18 \%$, means that $72.18 \%$ firm value can be explained by the corporate governance and family ownership, me a n while the $27.82 \%$ is explained by the other variables.

The increasing in board size tend to decrease firm value, the large number of directors can burden the firm costs, for example, a higher salary cost, if the firm does not earn a high income, then it certainly will reduce the profits of the firm, therefore in the long term can reduce the firm value, while increasing in independent tend to increase firm value, therefore independent commissioner has a positive significant effect on firm value, can by explained that the existence of an independent commissioner is expected to help supervise the management's (directors) actions to act in accordance with the interests of the 
principal, thus in the long-term if directors act matched with the principal, thus it can increase the firm value.

Two variables: institutional and public in ownership structure has a positive significant influence on firm value. Although the public ownership have a small percentage in the ownership structure but have a significant effect to increase firm value.

\section{Conclusions}

The research results showed thay independent commissioner, board of director, public and institutional ownership has significant influence on non-financial firm value listed in Indonesia Stock Exchange period 2008 to 2018, while the managerial, family ownership and board of commissioner have no significant influence on firm value. Therefore the firm has to determine the proportion of board structure especially for the number of (i) director, (ii) independent commissioner, and (ii) ownership structure such as public and institutional ownership, firm need to properly consider the decisions related to increasing or decreasing the size of director or the decision to change the percentage of ownership (public and institutional), because every decision will give different effect on firm value. The research limitations are: (i) consider to use of a 11 Indonesian firm listed in the Indonesian Stock Exchange. (ii) consider to use moderating variables, example government regulation, the condition of macro economy, to assess the influence of corporate governance on firm value

\section{References}

1. C.-P. Yeh, K.-M. Wang, K.-C. Chai, Expert Systems with Applications, 37,6:46714679(2010). https://doi.org/10.1016/j.eswa.2009.12.041

2. Z. Isshaq, G.A. Bokpin, and O.J. Mensah, Journal of Risk Finance, 10,5:488499(2009). https://doi.org/10.1108/15265940911001394

3. K. Heenetigala, and A.F. Armstrong. 2012. Financial Markets \& Corporate Governance Conference (2012). p. 17. http://dx.doi.org/10.2139/ssrn.1971927

4. S. Purkayastha, R. Veliyath, R. George, Journal of Business Research, 98:50-64. (2019). https://doi.org/10.1016/j.jbusres.2019.01.024

5. R. Barontini, L. Caprio, European Financial Management, 12:689-723(2005). https://onlinelibrary.wiley.com/doi/abs/10.1111/j.1468-036X.2006.00273.x

6. PwC Indonesia. Survey Bisnis Keluarga 2014 Indonesia. [2014 Indonesian Family Business Survey], https://www.pwc.com/id/en/publications/assets/indonesia-reportfamily-business-survey-2014.pdf (2014).

7. C. Andres, Family ownership as the optimal organizational structure? EFA 2006

Zurich Meetings, SSRN Electronic Journal (2007). p. 38. https://doi.org/10.2139/ssrn.903710

8. P. Thavikulwat, Simulation \& Gaming, 35,2:242-269(2004). https://journals.sagepub.com/doi/10.1177/1046878104263545

9. T. Pujiastuti, Jurnal Keuangan dan Perbankan, 2,12:183-197(2008). [in Bahasa Indonesia]. https://media.neliti.com/media/publications/108689-ID-none.pdf

10. M. Nakabayashi Institutions and Money, 61:189-212(2019). https://doi.org/10.1016/j.intfin.2019.03.003

11. V. Blanco-Mazagatos, Journal of Family Business Strategy, 7,3:167-177(2016). https://doi.org/10.1016/j.jfbs.2016.07.003

12. I. Ciftci, E. Tatoglu, G. Wood, M. Demirbag, S. Zaim, International Business Review, 28,1:90-103(2019).. https://doi.org/10.1016/j.ibusrev.2018.08.004 
13. M.S. Nazir, T. Afza, Future Business Journal, 4,1:139-156(2018).

https://doi.org/10.1016/j.fbj.2018.03.001

14. D. Miller, I.L. Breton-Miller, R.H. Lester, A.A. Cannella, Journal of Corporate Finance, 13:829-858(2007). https://asu.pure.elsevier.com/en/publications/are-familyfirms-really-superior-performers

15. E. Barth, T. Gulbrandsen, P. Schone, Journal of Corporate Finance, 11,1-2:107-127 (2005). https://www.sciencedirect.com/science/article/pii/S0929119904000252 